Hitit Üniversitesi İlahiyat Fakültesi Dergisi / Journal of Divinity Faculty of Hitit University

ISSN 2651-3978 / e-ISSN 2636-8110

(Aralık/December 2020) 19/2

\title{
JAPONYA'YA MÜSLÜMAN GÖÇÜ
}

MUSLIM IMMIGRATION TO JAPAN

\section{Elif BüşRa Kocalan}

Arş. Gör., Hitit Üniversitesi İlahiyat Fakültesi, Felsefe ve Din Bilimleri, Din Sosyolojisi Anabilim Dall, Çorum, Türkiye

Research Assistant, Hitit University Divinity Faculty, Philosophy and Religious Studies, Sociology of Religion Department, Corum, Turkey

ebusrakocalan@hitit.edu.tr

https://orcid.org/0000-0002-8051-4647

\begin{tabular}{|rl|}
\hline MAKALE BILGISI & ARTICLE INFORMATION \\
Makale Türü & Article Types \\
\hline Araştırma Makalesi & Research Article \\
Geliş Tarihi & Received \\
15 Şubat 2020 & 15 Fabruary 2020 \\
Kabul Tarihi & Accepted \\
22 Eylül 2020 & 22 September 2020 \\
Yayın Tarihi & Published \\
30 Aralık 2020 & 30 December 2020 \\
Yayın Sezonu & Pub Date Season \\
Aralık & December \\
Doi & \\
https://doi.org/10.14395/hititilahiyat.689578 & \\
\hline
\end{tabular}

\section{Atif/Cite as:}

Kocalan, Elif Büşra, “Japonya’ya Müslüman Göçü”, [Muslim Immigration to Japan], Hitit Üniversitesi İlahiyat Fakültesi Dergisi- Journal of Divinity Faculty of Hitit University 20/1 (December 2020): s. 733-757.

\section{İNTIHAL/PlagiaRISM:}

Bu makale, en az iki hakem tarafından incelendi ve intihal içermediği teyit edildi. This article has been reviewed by at least two referees and scanned via plagiarism software. Copyright (C) Published by Hitit Üniversitesi, İlahiyat Fakültesi - Journal of Divinity Faculty of Hitit University, Çorum, Turkey. All rights reserved. 


\section{Muslim Immigration to Japan}

\section{Abstract}

The encounter between Muslims and Japan coincides with the end of the 19th century. Japan, whom has closed itself to most of the world for about 250 years during the Tokugawa period, opened its doors to the world with the influence of the United States in 1853 and started to establish communication with many countries of the world. Following this, the encounters with Muslims and Islamic world also started. The first Muslims that arrived in Japan are thought to be merchants who came with the commerce ships. Thus, the journey of Muslims to Japan began with Indian Muslim merchants towards the end of the 19th century. Turko-Tatar Muslims who took shelter in Japan following the Russo-Japanese war in 1905 comes as the second significant Muslim immigrant group in Japan. During and after the Second World War the immigration slows down and the Indian and Turko-Tatar Muslims either returns to their homelands or immigrate other third countries. In the years following the war, although there were some individual visits, no significant migration activity from the Muslim countries is occurred. The third immigration wave coincides with the bubble economy of Japan after the 1970's. Many who sought better work conditions and salaries from countries such as Indonesia, Pakistan, Bangladesh and Iran found themselves in Japan.

The current the number of Muslims in Japan, including short time migrants who came to work or study, residents who had already settled in the country, had families and started to raise second generations, and Japanese Muslims, is around 150,000. ${ }^{1} \% 10$ of this number is considered as Japanese Muslims and the rest as immigrants. In the contemporary Japanese society, immigrant Muslims have a life away from discrimination, and do not have significant problems on fulfilling their religious needs with increasing number of mosques, masjids, Islamic organisations and halal food services. On the other hand, they still do not feel that they are being accepted as local members of the society.

The aim of this study is to describe the Muslim migration history in Japan, and to analyse the current situation of migrants in Japan. In order to do this, the literature and the field study data derived in between 2016 September-2017 December and 2019 February-2010 January will be consulted. In this paper, we tried to explain that although the Muslim migration history to Ja-

Hirofumi Tanada.『-2018 年』(Dünyada ve Japonya'da Müslüman Nüfus, 2018), 早稲田大学 人間科学研究 (Waseda Üniversitesi Beşeri Bilimler Fakültesi Araştırmaları), Vol: 32-2 (2019): 253 -262 . 
pan has started more than a century ago, immigrant Muslims are still having hardships on being accepted as permanent part of the Japanese society. This could be of two reason. Firstly, due to unstable migration waves, and immigrants returning to their homelands or migrating to other countries, there was not a stable Muslim population in Japan until 80's. Although first mosques and education centers were established a long time ago, the number of Muslims in Japan has only started to increase after the migration wave of 70s. Secondly, Japanese has a habit of seeing foreigners as guests, on the grounds that foreigners cannot learn Japanese sufficiently and cannot adapt to Japanese customs, hence can never live like a Japanese. Because of these reasons, immigrant Muslims still have difficulty of feeling a belonging to the country they are residing in. However, the more they live in the country and the more they become proficient in the language, the more their life satisfaction increases, and they start to have meaningful relationships with the locals.

Keywords: Sociology of Religion, Migration, Japan, Muslim Immigration, Muslims in Japan.

\section{Japonya'ya Müslüman Göçü}

\section{Öz}

Japonya ile Müslümanların karşılaşması 19. yüzyılın sonlarına denk gelmektedir. Tokugawa döneminde yaklaşık 250 yıl boyunca kendini dünyanın büyük bir kısmına kapatan Japonya, 1853 yılında Amerika Birleşik Devletleri'nin etkisiyle dünyaya kapılarını açmış ve dünyanın birçok ülkesi ile iletişim kurmaya başlamıştır. Müslümanlar ve İslam dünyasıyla karşılaşması da bu dönemin ardından olmuştur. Japonya'ya ilk gelen Müslümanların ticaret gemileriyle gelen tüccarlar olduğu düşünülmektedir. Böylece, Müslümanların Japonya'ya yolculuğu, 19. yüzyılın sonlarına doğru Hintli Müslüman tüccarlarla başlamıştır. 1905 Rus-Japon savaşından sonra Japonya'ya sığınan Türk-Tatar Müslümanlar, Japonya'daki ikinci önemli Müslüman göçmen grubudurlar. İkinci Dünya Savaşı sırasında ve sonrasında Hintli ve Türk-Tatar Müslümanlar ya anavatanlarına dönmüş ya da başka ülkelere göç etmişler ve göç açısından durağan bir döneme girilmiştir. Savaşı takip eden yıllarda iş ve eğitim gibi bazı amaçlar ile yapılan bireysel ziyaretler dışında Müslüman ülkelerden önemli bir göç faaliyeti yaşanmamıştır. Üçüncü göç dalgası, 1970’lerden sonra Japonya'nın ekonomik açıdan hızla geliştiği ve yabancı iş gücü göçünün başladığı döneme denk gelmektedir. Bu dönemi takiben Endonezya, Pakistan, Bangladeş ve İran gibi 
ülkelerden daha iyi çalışma koşulları ve maaş arayan birçok kimse kendilerini Japonya'da bulmuştur. Onları, yoğunlukla çalışmak ve okumak amaçlı gelen Endonezyalı ve Malezyalı Müslüman stajyerler takip etmektedir.

Günümüz Japonya'sındaki Müslüman sayısı, son dönemde iş veya eğitim sebebiyle ülkeye kısa bir süreliğine gelen göçmenler, 1970'ler sonrası çalışmak için gelmiş, ülkeye yerleşmiş, aile kurmuş ve ikinci nesilleri yetiştirmeye başlayan yerleşik göçmenler ve Japon Müslümanlar da dâhil olmak üzere tahminen 150.000 kişi civarındadır. Bu sayının\% 10’u Japon Müslümanlar, geri kalanı ise göçmen olarak kabul edilmektedir. Çağdaş Japon toplumunda göçmen Müslümanlar ayrımcılıktan uzak bir yaşam sürmekte ve sayıları gün geçtikçe artan cami, mescit, İslami kuruluşlar ve helal yemek hizmetleri ile dini ihtiyaçlarını karşılamada önemli sorunlar yaşamamaktadır. Öte yandan, toplumun kalıcı üyeleri olarak kabul görmede birtakım problemler ile karşılaşmaktadırlar.

Bu çalışmanın amacı Japonya'ya Müslüman göçü tarihini gözden geçirmek ve Japonya'daki göçmenlerin mevcut durumunu incelemektir. Bunun için, 2016 Eylül - 2017 Aralık ile 2019 Şubat ve 2020 Ocak dönemleri arasında toplam 2 buçuk yıl Tokyo'da sürdürülen kütüphane ve saha çalışmasında toplanılan literatür ve gözlem verilerine başvurulacaktır. Japonya'ya Müslüman göçü tarihi bir asırdan fazla bir süre önce başlamasına rağmen, göçmen Müslümanların Japon toplumunun kalıcı bir parçası olarak kabul edilmekte hala güçlükler yaşadığı görülmektedir. Bunun iki nedeni olabilir. Birincisi, istikrarsız göç dalgalarıdır. Göçmenlerin İkinci Dünya Savaşı sırası ve sonrasında anavatanlarına dönmeleri veya başka ülkelere göç etmeleri sebebiyle, Japonya'da 80'i yıllara kadar sabit bir Müslüman nüfus oluşmamıştır. İlk camiler ve eğitim merkezleri uzun zaman önce kurulmasına rağmen Japonya'daki Müslümanların sayısı ancak 70'i yıllardaki göç dalgasından sonra istikrarlı bir şekilde artmaya başlamıştır. İkincisi ise, Japon toplumu, bir yabancının Japoncayı yeterince öğrenmesinin mümkün olmayacağı ve Japon toplumsal hayatına ve kurallarına uyum sağlayamayacağı düşüncesiyle asla bir Japon gibi yaşayamayacağı kanısında olup yabancıları misafir olarak görme alışkanlığına sahiptir. Bu yüzden de, göçmen bir Müslüman Japonya'da ne kadar uzun yaşamış olursa olsun, bir işi ve ailesi de olsa bile, toplum tarafından geçici ve misafir olarak görülebilmektedir. Bu durum göçmen bir kimsenin başarılı bir şekilde sosyalleşmesinin ve topluma aidiyet hissetmesinin önünde bir engel oluşturmaktadır. Ancak, göçmenlerin ülkedeki kalış süreleri uzadıkça ve dile hakimiyetleri arttıkça Japon toplumuna olan uyumları da artmaya başlamakta, ev sahipleri ile gittikçe daha anlamlı ilişkiler kurmakta ve Japonya'daki yaşamlarından memnuniyetleri artmaktadır. 
Anahtar Kelimeler: Din Sosyolojisi, Göç, Japonya, Müslüman Göçü, Japonya'da Müslümanlar

\section{Giriş}

Japonya'nın Müslümanlar ile tanışmasının 150 yıl kadarlık bir geçmişi vardır. Ülkenin samuraylar tarafından yönetildiği 250 yıllık Tokugawa Dönemi'nde diğer ülkeler ile iletişim, ticaret ve seyahatler neredeyse kendini dünyaya kapatmak denilebilecek derecede kısıtlanmıştır. Coğrafi konum sayesinde de bu durum uzunca bir süre devam ettirilebilmiştir. Bu durum, ülkede bu süre içinde barış içinde yaşanmasını sağlamış olsa da, dünyanın birçok ülkesi, kültürü ve insanı ile tanışılmasını da son derece geciktirmiştir. 1853 yılında Yokohama limanına ulaşan ve ülkenin ticarete açılmasını talep eden Amerikan gemileri sonrasında ülke ticari, siyasi ve kültürel olarak d1şarıya açılmıştır. Japonya'ya gelen ilk Müslümanların da ticaret amaçlı gelen kimseler olduğu düşünülmektedir. Günümüze kadar olan yaklaşık bir buçuk yüzyıllık bu süreçte farklı dönemlerde çeşitli sebepler ile farklı ülkelerden Japonya'ya Müslüman göçleri gerçekleşmiştir.

Japonya'ya Müslüman göçü, dünyanın birçok bölgesine kıyasla nispeten daha az boyutlarda ve geçici dönemlerde gerçekleşmiştir. Özellikle ilk dönem göçmenler Japonya'da uzunca bir süre yaşayıp dernekler, eğitim kurumları, ibadet mekânları oluşturmalarına rağmen ülkede kalıcı olmamış, başka ülkelere göç etmek ya da ülkelerine geri dönmek durumunda kalmışlardır. Illk dönem göçmen gruplarından Hintli ve Tatar Müslüman göçmenler bunlara örnektir. Camiler, dernekler, okullar ve matbaalar kurmalarına, ülke tarafından ciddiye alınacak büyüklükte bir topluluk oluşturmalarına rağmen, İkinci Dünya Savaşı ve takip eden dönemde ülkeden ayrılmaları gerekmiştir. Bu sebeple göç tarihinin başlamasından itibaren Japonya'da istikrarlı olarak artan bir Müslüman nüfus olmamıştır. Ülkedeki Müslüman göçmenlerin sayısı dönem dönem artmış, dönem dönem yok denecek derecede azalmıştır. 1970'lerde hızlı ekonomik büyüme sonrası ülkeye çalışma amacıyla göç eden, çoğunluğu İran, Bangladeş, Pakistan, Endonezya ve Malezyalı göçmenlerin ülkelerine geri dönmemeleri ve evlenerek Japonya'da bir yaşam kurmayı tercih etmeleri ülkedeki Müslüman göçmen nüfusun daha istikrarlı hale gelmesini sağlamıştır. Evlenip Japonya'da kalmayı tercih eden bu göçmenler sonrasında, ikinci kuşak göçmen fenomeni yakın zamanda toplumda gözlemlenmeye başlanmış, Müslüman çocuklar, onların eğitimi ve okuldaki beslenme saatleri gibi durumlar yeni yeni Müslüman ailelerin ve Japon toplum bilimcilerin gündeminde yer almaya başlamıştır. 
Son bir buçuk yüzylllık süreçte farklı ülkelerden Müslüman göçü gerçekleşmiş olmakla birlikte, en belirgin olarak nitelendirilebilecek göçmen grupları ülkeye farkı dönemlerde gelmiş olan Hintli Müslüman tüccarlar, Tatar göçmenler, Pakistanlı, Bangladeşli, İranlı ve Türk göçmenler ve son olarak Endonezya ve Malezyalı göçmenlerdir. Son yapılan araştırmalara göre, eğitim yahut iş amacıyla geçici bir süre için gelenler ve hâlihazırda Japonya'da yerleşmiş ve hayatlarını orada sürdüren göçmen Müslümanlar ve Japon Müslümanlar ile birlikte 150,000 civarı Müslüman olduğu tahmin edilmektedir. ${ }^{2}$

Bu çalışmanın amacı Japonya'ya Müslüman göçü tarihini ve güncel durumu incelemektir. Çalışma için gerekli veriler Japonya, Tokyo'da 2016 Eylül2017 Aralık ve 2019 Şubat-2020 Ocak tarihleri arasında toplam iki buçuk yıla yakın bir süre gerçekleştirilen saha ve kütüphane çalışması sırasında toplanmıştır. Göçmen Müslümanların tarihi ve topluluk oluşturma çabaları literatür analizi ve saha çalışması sırasında edinilen gözlem verileri bağlamında değerlendirilecektir.

\section{1800'lerin Sonları - Hintli Müslüman Göçmenler}

Müslümanların Japonya'ya göç tarihi genellikle tarih 1905 Rusya-Japonya savaşı ve Tatar göçmenler ile başlatılır. Ancak Tatarlar öncesi Japonya'ya yerleşen başka bir Müslüman topluluk daha bulunmaktadır. Hintli Müslümanlar, 1800'lerin sonlarında ticaret amaçlı gelmeye başlayıp dönemin ticaret merkezleri Yokohama ve Kobe gibi şehirlere yerleşmişlerdir. ${ }^{3}$ Ancak, sonradan gelen Tatar Müslümanlar ile karşılaşıp iş birliği yapıncaya kadar Japonya'da kendilerini ve İslam'ı tanıtmak ya da İslamiyet'i yaymak gibi herhangi bir çabaları olmamıştır. Bu sebeple Japonya'daki erken dönem varlıkları fazla bir iz bırakmamış, son dönem yapılan araştırmalara kadar da -en azından Japonya'da İslam tarihi araştırmacıları tarafından- keşfedilememişlerdir.

Hintli tüccarlar Japonya'ya 1800’lerin sonlarına doğru ulaşmışlardır. İpek ticaretinin merkezi olan Yokohama Hintli tüccarların ticaret merkezlerinden biri haline gelmiştir. ${ }^{4}$ Başarılı Hint şirketlerinin birkaçı Kobe'de, çoğunluğu Yokohama'da olmak üzere şube açmaya başlamış, buna karşılık Yokohama merkezli bir banka da 1894'te Bombay'da bir şube açmıştır. 1920'lere gelindi-

Tanada,『世界と日本のムスリム人口-2018 年』(Dünyada ve Japonya'da Müslüman Nüfus, 2018), 253-262.

3 Ali Merthan Dündar, , Japonya'da Türk İzleri: Bir Kültür Mirası Olarak Mançurya ve Japonya Türk-Tatar Camiileri (Ankara: Vadi Yayınları, 2008), 47.

4 Claude Markovits, The Global World of Indian Merchants, 1750-1947: Traders of Sind from Bukhara to Panama (Cambridge: Cambridge University Press, 2000), 146. 
ğinde ise Yokohama'da 30 civarında Hint şirketi bulunmaktadır. ${ }^{5}$ Bu dönemde Hintli Müslüman tüccarlar Japon ürünlerinin ihracatında önemli rol oynamışlardır. ${ }^{6} 1904$ 'te de Kobe'de bir Hindistan Kulübü açmış, orada bir araya gelmiş, toplu ibadetlerini yerine getirmiş ve sosyalleşmişlerdir. ${ }^{7}$

Hintli Müslüman toplulukların Japonya'daki erken dönem -1900'ler öncesi- varlıkları, 1897 yılında Yokohama otoritelerinden şehirde bir Müslüman mezarlığı oluşturabilmek için aldıkları izin ile anlaşılmaktadır. ${ }^{8}$ Mezarlık, bir ülkede azınlık olarak yaşayan bir Müslüman topluluğun, helal yiyecek ve ibadet mekanı ile birlikte önde gelen ihtiyaçlarındandır. 1897'de mezarlığa ihtiyaç duyabilmeleri için ülkeye bir süredir yerleşmiş bir Müslüman topluluk olması gerekmektedir. Fakat yukarıda da ifade edildiği gibi, bu dönemde kendilerini ve İslam'ı tanıtmak gibi bir çabaları olmadığı için erken dönem varlıkları araştırmacıların dikkatlerinden kaçmıştır. Nitekim Japonya'da ikamet eden ve Japonya'nın İslamlaşıp İslamlaşmadığını araştıran Amerikalı bir sosyal bilimci, araştırmaları sonucunda 1906 yılında Japonya'da Müslüman misyonerlerin olmadığı ve dolayısıyla Japonya'nın İslamlaşmadığı sonucuna varmıştır. ${ }^{9}$ Onu bu araştırmaya yönelten husus 1905 Rus-Japon savaşı ve Japonya galibiyeti sonrası İslam ülkelerinde entelektüeller tarafından kurulmaya başlanan İslam'ın kurtarıcısı Müslüman Japonya hayalidir. Ancak anlaşıldığı üzere 1890'larda Yokohama'ya ticaret amaçlı gelmeye başlayan, bir topluluk oluşturan, hatta kendilerine mezar yeri izni bile alma ihtiyacı duyacak kadar ülkeye yerleşen Hintli Müslümanların böyle bir misyonları ve aktiviteleri yoktur ki, bu erken dönemde İslam'ı yaymak için çalışan kimseye rastlanmamıştır.

1909 yılında Japonya'ya gelen ve Tokyo Üniversitesi'nde Hintçe öğretmeye başlayan siyasi aktivist Mohammad Barakatullah, Hintli göçmen Müslümanları İslam'ı Japonya'ya anlatmaları yönünde teşvik eden ilk isimlerden biri olarak kabul edilebilir. Barakatullah, 1910 yılında Japonya'nın ilk İslami dergisi olarak kabul edilen The Islamic Fraternity'yi yayınlamaya ve İslam'1 Ja-

5 Nile Green, "Shared Infrastructures, Informational Asymmetries: Persians and Indians in Japan, c.1890-1930", Journal of Global History, No: 8 (2013): 424.

6 Takashi Oishi, "Indo-Japan Cooperative Ventures in Match Manufacturing in India: Muslim Merchant Networks in and beyond the Bengal Bay Region 1900-1930", International Journal of Asian Studies, No: 1:1, (2004): 50.

7 Dündar, Japonya'da Türk İzleri: Bir Kültür Mirası Olarak Mançurya ve Japonya Türk-Tatar Camiileri, 53.

8 Ulrich Brandenburg, “Imagining an Islamic Japan: Pan-Asianism's Encounter with Muslim Mission", Japan Forum, Vol: 0: 0 (2018): 13.

$9 \quad$ Ulrich, “Imagining an Islamic Japan", 13. 
ponlara, Japonya'yı Müslümanlara anlatmaya başlamış ve Hasan Hatano Uho gibi isimlerin Müslüman olmasına vesile olmuştur. ${ }^{10}$ Ayrıca Yokohama'da yaşayan Hint Müslüman topluluklarla birlikte Tokyo'da bir cami inşa etmeyi de planlamıştır ancak başarılı olamamıştır. ${ }^{11}$ Pan-İslam politikası yürüten ve aynı zamanda İngilizlerin Hindistan'daki varlığına karşı olan Barakatullah'ın İngilizce yayınlanan dergisi The Islamic Fraternity, İngiliz elçiliğinin baskıları sonucu 1912 yılında yasaklanmıştır. Barakatullah, üniversitedeki iş anlaşmasının da yenilenmemesi sebebiyle 1913 yılında Japonya'dan ayrılmak durumunda kalmıştır. ${ }^{12}$

Tatar Müslümanlar 1905'ten sonra Rusya'dan kaçıp Japonya'ya yerleşmeye başlayıp Japon devlet adamları ve askeriyesi ile ilişkiler kurup işbirliği yapmaya başladıktan sonra, Hintli Müslümanlar onlar ile birlikte Japonya'da İslam'ı tanıtma ve yayma ve kendileri için daha organize dini hayatlar kurma yolunda çalışmaya başlamışlardır. Nitekim Japonya'daki ilk cami, 1935 yılında Kobe'de, Hint ve Tatar Müslümanların işbirliği ile açılmıştır. ${ }^{13} 1934$ yılında Kobe'de 94 Hintli ve 130 Türk-Tatar Müslüman yaşamaktadır. Cami için gerekli para Japonya'da kendi aralarında ve Hindistan'da topladıkları bağışlar yoluyla sağlanmıştır. Kobe Camii'nin ilk imamı Hintli bir Müslümandır. Kobe'de yaşayan Müslüman topluluklar için bir sosyal mekân haline gelen camide, ayrıca Türk-Tatar çocukların eğitimlerine de devam edilmiştir. ${ }^{14}$

\section{1905 Rus- Japon Savaşı - Tatar Müslüman Göçmenler}

Tatar Müslümanlar, 1900'lerin başlarından itibaren, tam da Japonya'nın Asya'ya yayılma politikası izlediği bir dönemde ülkeye sığınmaya başlamış ve Tokyo ve civarı illere yerleşmişlerdir. Japonya'nın o dönemdeki politikasını kendileri için bir fırsat olarak görüp politik ve askeri alandaki üst düzey insanlar ile iletişim kurup, Japonya'nın Pan-Asyacılık politikası ile kendi Pan-İslam politikalarını birleştirip, Asya'nın hâkimi ve Asyalı Müslümanların da lideri ve koruyucusu konumunda olan bir Japonya oluşturmaya çalışmışlardır. Milliyetçi Japon siyasetçiler, entelektüeller ve askerler kalabalık

10 Renée Worringer, "Hatano Uho: Asia in Danger, 1912", Pan-Asianism - A Documentary History Volume 1: 1850-1920, ed. Sven Saaler, Christopher W. A. Szpilman (Plymouth: Rowman \& Littlefield Publishers, Inc., 2011), 149.

11 Ulrich, "Imagining an Islamic Japan”, 16-17.

12 Cemil Aydın, The Politics of Anti-Westernism in Asia - Visions of World Order in Pan-Islamic and Pan-Asian Thought (New York: Columbia University Press, 2007), 206.

13 Hirofumi Tanada, 『日本のモスク・滞日ムスリムの社会的活動』 (Japonya Camileri ve Japonya'da Yaşayan Müslümanlarm Sosyal Faaliyetleri) (Tokyo: Yamakawa, 2015).

14 Dündar, Japonya'da Türk İzleri: Bir Kültür Mirası Olarak Mançurya ve Japonya Türk-Tatar Camiileri, 62. 
Asyalı Müslüman nüfusun gönüllerini kazanarak onları müttefik edinmenin Japonya'nın Asya'daki yayılma politikasına katkısı olacağı düşüncesiyle Tatar Müslümanlara büyük destek vermişlerdir.

Tatar Müslümanların Japonya'yı seçmesi tesadüfi bir durum değildir. 1895 Çin-Japon ve 1905 Rus-Japon savaşlarında galip gelen, Meiji döneminde ekonomik ve askeri açıdan hızla gelişen Japonya, Asya'nın önde gelen ülkelerinden biri olmaya başlamıştır. Bu dönemde Asya'yı daha derin keşfetmeye, Asyalı halkları tanıyıp potansiyel müttefikler aramaya başlamışlardır. RusJapon savaşı sonrasında da Japonya Rusya'nın rakibi haline gelmiştir. Bütün bunları göz önünde bulundurunca, Rusya ile problem yaşayan Tatar Müslümanların Japonya ile iletişim kurduktan sonra bu ülkeye sığınmalarının son derece mantıklı bir seçim olduğu görülmektedir.

1917 Bolşevik İsyanları sonrası Japonya'ya ikinci bir Türk kökenli göçmen dalgası (Tatar, Kırgız, Başkır...) olmuştur. Başka bir önemli isim, Muhammed Abdülhay Kurbanali de ikinci dalga göçmenlerdendir. ${ }^{15}$ Türk-Tatar göçmenler milli ve dini kimliklerini koruyabilmek amacı ile sık sık bir araya gelip ibadetleri birlikte yapmaya, bayramları birlikte kutlamaya çalışmışlardır ancak, Kurbanali'nin gelişi ve liderliklerini üstlenişi ile daha organize bir grup haline gelmişlerdir. ${ }^{16}$ Tokyo'da yaşayan 200-300 civarı Türk-Tatar Müslüman, Kurbanali liderliğinde 1928 yılında Mahalle-i İslamiyye adlı bir dernek, sonrasında da hem çocuklarının eğitimi için hem de kendileri için bir toplanma alanı olarak Mekteb-i İslamiyye adlı bir okul kurmuşlardır. 1930'da kurdukları Matbaa-i Íslamiyye adlı yayınevi ile de çocuklarının okul kitabı problemini çözmüşlerdir. ${ }^{17}$ Türk-Tatar çocukları Tokyo ile birlikte Nagoya ve Kobe gibi şehirlerde de kurulan okullarda İslami ilimleri öğrendikleri gibi, Tatarca, Japonca ve İngilizce eğitimi de almışlardır. ${ }^{18}$ Kurulan matbaada ayrıca Yeni Yapon Muhbiri adlı aylık gazete ile de Japonya'yı Müslümanlara, Müslümanları da Japonya'ya tanıtmaya çalışmışlardır. ${ }^{19}$

Başka bir isim, Tatar gazeteci ve entelektüel Abdürreşit İbrahim (1853-

15 Sinan Levent, "Japan's Central Eurasian Policy: A Focus on Turkic Muslim Minorities", Social Science Japan Journal, Vol. 22: 1 (2019): 131.

16 Ali Merthan Dündar, "An Essay on the Immigration of the Turk-Tatars to Japan", Annual Journal of the Asian Cultures Research Institute, No: 48 (2013): 168-169.

17 Levent, “Japan's Central Eurasian Policy: A Focus on Turkic Muslim Minorities”, 133.

18 Sayako Numata, "Fieldwork Note on Tatar Migrants from the Far East to the USA: For Reviews of Islam Policy in Prewar and Wartime Japan", AJAMES, No: 28-2 (2012): 132-133.

19 Hisao Komatsu, "Abdurresit İbrahim and Japanese Approaches to Central Asia", Japan on the Silk Road -Encounters and Perspectives of Politics and Culture in Eurasia, ed: Selçuk Esenbel (Leiden: Brill, 2018), 150. 
1944) ülkeye gelen ilk Tatar Müslüman olarak kabul edilmekle birlikte ${ }^{20}$, Türk-Tatar Müslümanların liderliğini üstlenmesi 1938 yılında, Kurbanali'nin Japonya'dan ayrılmasından sonra olmuştur. ${ }^{21}$ İbrahim, Japon askeriyesinin üst düzey yetkilileri ile ilk defa Rusya'da iletişim kurmuş, sonrasında sıklıkla gerçekleştirdiği Japonya seyahatlerinde Japonların kültür, yaşam ve ahlaklarından da etkilenerek Pan-Asya politikası yürüten milliyetçi gruplar ile işbirliği yapmaya başlamıştır. 1909 yılında ortak hedefleri olan Asyalı Müslümanlar ile Japonya'yı bir araya getirme ve Asya birliği sağlama amaçlı Ajia Gikai adlı siyasi bir grup kurmuşlardır. ${ }^{22}$ Japonya ile Osmanlı arasında gönüllü elçi gibi çalışmış, Japonya'yı İslam'a yakın adet ve ahlakları ve gelişmişlikleri ile Batı'ya alternatif olarak tanitıp Osmanlı entelektüelleri arasında Japonya hayranlığının oluşmasına sebep olmuştur. ${ }^{23}$

Bu dönemde göçmen Müslümanlar Japonya'da üç büyük cami kurmuşlardır. Bunlardan ilki, Hint ve Türk-Tatar toplulukların işbirliği ile Kobe'de 1935 yılında kurulmuştur. Dönemin Kobe'sinde bu caminin mensubu 250'ye yakın Hint ve Türk-Tatar göçmen olduğu bildirilmektedir. 1936 yılında ise, sayılarının 30 ya da 60 arası olduğu düşünülen Türk-Tatar bir topluluk tarafından Nagoya'da ikinci cami kurulmuştur. Sayıca diğer şehirlerdeki göçmen gruplardan daha az olmalarına rağmen son derece organize ve aktif bir topluluk oldukları söylenmektedir. Son olarak da 1938 yılında Tokyo Cami açılmıştır. ${ }^{24}$

Türk-Tatar liderlerin ve Japon politikacıların ümit ettiği Asya birliği gerçekleşmemiş olsa da, bu çabalar Japonya'da İslam üzerine bir farkındalık oluşmasını sağlamıştır. İslam üzerine araştırma enstitüleri kurulmuş, makaleler ve kitaplar yayınlanmaya başlanmış, gazeteler sıklıkla İslam hakkında yazı ve haberler verir olmuş ve ülkede camiler inşa edilmeye başlanmıştır. Tokyo Camii Tatar Müslümanlar ile Japon politikacılarının işbirliğinin bir sembolü olarak, Japon işadamlarının da büyük bağışları ile inşa edilmiştir. ${ }^{25}$

20 Dündar, "An Essay on the Immigration of the Turk-Tatars to Japan", 167.

21 Levent, “Japan's Central Eurasian Policy: A Focus on Turkic Muslim Minorities", 134.

22 Hisao Komatsu, "Muslim Intellectuals and Japan: A Pan-Islamist Meditator, Abdurresit Ibrahim", Intellectuals in the Modern Islamic World: Transmission, Transformation and Communication, ed. Stephane A. Dudoignon, Komatsu Hisao, Kosugi Yasushi (London: Routledge, 2006), 278.

23 Selçuk Esenbel, "Abdürreşit İbrahim: "The World of Islam and the Spread of Islam in Japan" 1910", Pan-Asianism - A Documented History, Volume I: 1850-1920, ed: Sven Saalar, Christopher W. A. Szpilman (Plymouth: Rowman \& Littlefield Publishers, Inc., 2011), 195-196.

24 Dündar, Japonya'da Türk İzleri: Bir Kültür Mirası Olarak Mançurya ve Japonya Türk-Tatar Camiileri.

25 Komatsu, "Muslim Intellectuals and Japan: A Pan-Islamist Meditator, Abdurresit Ibrahim", 284. 
Japonya'da İslam hakkında bilginin ilk defa Batılı yazarların eserlerinden öğrenildiği düşünülmektedir. ${ }^{26}$ Japonya'ya Müslüman göçünün 19. yüzyılın ancak sonlarına doğru olması ve göçmen Müslümanların İslam'ı tanıtmak için aktif çaba göstermesinin ise Tatar Müslümanların gelişinden sonra başlaması da bu düşünceyi tarihler açısından doğrulamaktadır. 1853'te kapıların dışarıya açılmasından kısa süre sonra, henüz Müslüman göçü başlamamışken, Hristiyan misyonerler dönüş yapmıştır. 1868'de ülkeye tekrar giriş yapmaya başlamış olan Hristiyan misyonerlere karşı halkı uyarmak için dağıtılmış Tales of Nagasaki - The Story of the Evil Doctrine isimli kitapçıkta "Nagasaki limanının açııı̧ından itibaren Batılı barbarların arasında Fransızlar yoğunlukla Roman Katolik dinini, İngiliz ve Amerikalılar Protestan dinini telkin etmeye başlamışlardır. Bunlara ek olarak Yunan dini, Muhammed'in dini ve benzerleri de vardır ve her biri bir öncekini andırmakta ve zararda yarışmaktadırlar" ${ }^{27}$ ifadesi geçmektedir. Buradan anlaşıldığı üzere 1868 yılında İslam dini Japonya'da bilinmeye başlanmış, Batılı dinler ile aynı çerçevede, birbirlerinin benzeri olarak değerlendirilmiştir. Tatar Müslümanların milliyetçi Japon politikacılar ve entelektüeller ile yaptıkları işbirliği sonucunda ülkede İslam'ı olduğu gibi, Batı'nın önyargısından ve/veya yanlış anlatısından arındırarak anlama çabaları başlamıştır. ${ }^{28}$ Kurulan araştırma enstitüleri Müslümanlar tarafından kurulmamış ve yönetilmemiştir, ancak İslam'ın anlaşılmasında büyük katkıları olmuştur.

İkinci Dünya Savaşı öncesi Japonya'daki Türk-Tatar nüfusun 1000'den fazla olduğu tahmin edilmektedir. 1945 sonrası birçoğunun Türkiye ve Amerika'ya göç etmesi ile birlikte bu sayı giderek azalmıştır. ${ }^{29} \mathrm{Bu}$ dönemde Japonya'da kalan Türk-Tatar aile sayısı 10-15 civarındadır. ${ }^{30}$

\section{1945 Sonrası - Durağan Dönem}

İkinci Dünya Savaşı Japonya ekonomik, siyasi, askeri ve dini açıdan öncesinden bambaşka bir hal almıştır. Tokyo ve Kobe Camiileri ayakta kalmıştır ancak Nagoya Cami savaş sırasında yıkılmıştır. Ülkedeki göçmen Müslümanların çoğu ya başka ülkelere göç etmiş ya da iletişimi kaybedip birbirlerinden

\footnotetext{
26 Abu Bakr Morimoto, Islam in Japan - Its Past, Present and Future (Tokyo: Islamic Center Japan, 1980), 8.

27 Otis Cary, A History of Christianity in Japan - Protestans Missions (Michigan: Scholarly Press, 1970), 92.

28 Selçuk Esenbel, "Japan's Global Claim to Asia and the World of Islam", American Historical Review, Vol:109:4 (2004): 1142-1143.

29 Numata, "Fieldwork Note on Tatar Migrants from the Far East to the USA: For Reviews of Islam Policy in Prewar and Wartime Japan", 133-134.

30 Dündar, "An Essay on the Immigration of the Turk-Tatars to Japan", 170.
} 
bihaber kalmışlardır. İslami aktivitelere maddi ve manevi destek veren milliyetçi ve sağcı politikacıların güç kaybetmesi ile bir önceki dönemdeki cami açılışları ve akademik araştırma faaliyetleri yok denecek kadar azalmıştır. Müslüman göçü açısından durağan olan bu dönemde, göçmen Müslümanlar ile Japon Müslümanların sayısı da neredeyse eşit denecek seviyeye gelmiştir. Japonya'daki Müslüman göçmenlerin sayısı azalmıştır. Öte yandan savaş öncesi yahut savaş sırasında görevlendirildikleri ülkelerdeki yerel Müslüman halktan etkilenip Müslüman olmuş ve ülkeye dönmüss Japonlar ile birlikte Japon Müslümanların da sayısı artmıştır. Bu dönemde Japonya'daki göçmen Müslümanlar ile Japon Müslümanların 1500-2000'er kişi arasında olduğu düşünülmektedir. ${ }^{31}$ Göçmen Müslümanların da büyük bir çoğunluğunu Japonya'ya bir süreliğine eğitim için gelmiş öğrenciler, bürokratlar, iş adamları ve akademisyenler oluşturmaktadır. ${ }^{32}$ Müslümanların sayısının azlığı sebebiyle Tokyo ve Kobe'de kalan iki cami bir süre yeterli gelmiştir. ${ }^{33}$

Bu dönemde, gerek siyaseten İslam üzerindeki ilgi ve desteğin bitmesi, gerekse ülkeye yerleşen göçmen Müslümanların da sayısının azalması ile bir başlarına kalmış Japon Müslümanlar kendi kendilerine bir araya gelerek örgütlenmeye ve hem kendileri hem de ülkenin geri kalanının yararına İslami aktiviteler gerçekleştirmeye çalı̧̧ışlardır. Savaş sonrasında kurulan ilk İslami organizasyon, tamamı Japon Müslümanlardan oluşan bir ekip tarafından 1952 yılında kurulmuştur. Kuruluşundaki adı İslami Dostluk Derneği'dir. 1964 yılında Japon Müslüman Derneği olarak değiştirilmiş, ülke tarafından resmi olarak kabul gören ilk İslami organizasyon olmuştur. 1970 sonrası gelecek göç dalgasına kadar, ülkedeki İslami faaliyetler yoğunlukla bu organizasyon tarafından ve vesilesiyle gerçekleştirilmiştir.

İslam'ı daha iyi öğrenip daha iyi yaşamak ve ülkelerine de tanıtmak isteyen Japon Müslümanlar, ülkede geçici olarak bulunan uluslararası Müslüman öğrenci ve akademisyenler ile işbirliği yapmış, karşılıklı olarak birbirlerine destek olmuşlardır. Sayıca son derece azınlık oldukları bir ülkede

31 Higuchi Mimasaka, 「日本のイスラーム、戦後の歩みー20世紀後半から今まで」 (Japonya'nın İslam'1, Savaş Sonrası Tarih - 20. Yüzyıldan Günümüze), 『日本に生きるイス ラームー過去一現在一未来 』(Japonya'da Yaşayan İslam -Geçmiş-Günümüz-Gelecek), ed. Suudi Arabistan Büyükelçiliği Kültür Bölümü (Tokyo: Suudi Arabistan Büyükelçiliği Kültür Bölümü, 2010), 119.

32 Akiko Komura,『日本のイスラームー歴史・宗教・文化を読み解く』(Japonya'nın İslam'1 Tarih, Din ve Kültürü Okumak) (Tokyo: Asahi Shimbun Publications, 2019), 48-49.

33 Akira Hamanaka, 「 時計から見た日本のイスラーム」(İstatistiklerle Japonya'nun İslam'1 1 ), 『日本に生きるイスラームー過去一現在一未来 』(Japonya'da Yaşayan İslam -Geçmiş-Günümüz-Gelecek), ed. Suudi Arabistan Büyükelçiliği Kültür Bölümü (Tokyo: Suudi Arabistan Büyükelçiliği Kültür Bölümü, 2010), 130. 
farklı sebeplerle geçici olarak yaşayan yabancı Müslümanlar, Japon Müslüman grupların etkinliklerine katılarak, namazları birlikte kılarak yahut birlikte İslami etkinlikler organize ederek yalnız kalmaktan bir nebze kurtulmuşlardır. Karşılığında ise, kendi ülkelerindeki gazete, kitap, makale gibi İslami yayınları Japonya'ya getirip, Japoncaya tercüme edip, Japon Müslümanların faydalanabileceği yayınlar yapılmasına vesile olmuşlardır. Assalam dergisi, o dönemde bu tercüme yazı ve makalelere yer veren dergilerden biridir. ${ }^{34}$ Müslüman göçü açısından durgun geçen savaş sonrası bu dönemde, Japon Müslümanlar, İslam'ı daha iyi öğrenebilmek amacıyla İslami ülkelere öğrenci göndermeye başlamışlardır. 1957 ve 1970 yılları arasında 27 Japon Müslüman öğrenci, Mısır, Endonezya, Arabistan gibi ülkelerde İslami eğitim görmüş ve ülkelerine dönerek Japon Müslüman hareketinin önde gelen isimlerinden olmuşlardır. ${ }^{35}$

1956 yılına gelindiğinde, Pakistan'dan Tebliğ Cemaati Japonya'ya ulaşmıştır. 1956 ve 1960 yılları arasında 4 kez gidip gelerek, Japon Müslümanlar ile birlikte çalışarak Japonya'nın bir ucundan diğer ucuna geziler düzenleyip İslam'ı anlatmışlardır. Daha sonra Japon Müslümanlar arasında önemli yerleri olacak birçok isim, onların da vasıtasıyla Müslüman olmuştur. Tebliğ Cemaati'nin en büyük etkilerinden biri, Kur'an'ın ilk defa bir Japon Müslüman tarafından Japoncaya çevrilmesine vesile olmalarıdır. Japonca Kur'an çevirisini yapan Japon Müslüman Ömer Mita, Tebliğ Cemaati üyeleri Japonya'ya her geldiğinde onlara eşlik etmiş, en sonunda İslam üzerine daha iyi çalışmak için Pakistan'a taşınmış ve Kur'an çevirisine orada başlamıştır. ${ }^{36}$

Uluslararası Müslüman öğrenciler, 1961 yılında Müslüman Öğrenci Derneğini kurmuşlardır. Yine 1968 yılında, Japonya İslam Merkezi, Japon Müslümanlar ile birlikte faaliyet gösteren bir grup göçmen Müslüman tarafından kurulmuştur. ${ }^{37}$

Savaş sonrası ülkenin ekonomik, siyasi ve toplumsal açıdan huzursuz olduğu bu dönemde, ülkeye eğitim ya da iş gibi sebepler ile bireysel ziyaretlerin dışında, Müslüman göçü diye nitelendirilebilecek büyük bir göç fenomeni gözlenmemektedir. Ülkedeki cami ve dernek sayıları da Müslüman nüfusun azlığı ile orantılıdır. 1970'li yıllara gelinceye kadar Japonya'da toplam yalnız

34 Akiko Komura - 『日本とイスラームが出会うとき一その歴史と可能性』(Japonya ve İslam Karşılaştı̆̆ında) (Tokyo: Gendaishokan, 2015), 56.

35 Japan Muslim Association, Brief History of the Associaton-Publication in Memory of the 50th Anniversary, (Tokyo: Japan Muslim Association, 2005), 53-54.

36 Mimasaka,「日本のイスラーム、戦後の歩みー20世紀後半から今まで」, 110.

37 Komura,『日本のイスラームー歴史・宗教・文化を読み解く』, 50. 
5 adet cami, mescit ve İslami dernek bulunmaktadır. Bu durum 1970'li yıllardan sonra değişecektir.

\section{1970 ve Sonrası - Ekonomik Sebepli Göçler}

1970 sonrasında, göç ve İslami faaliyetler açısından savaş sonrası yaşanan durgunluğu değiştirecek iki büyük durum ortaya çıkmıştır. Bunlardan ilki, Japonya'nın 1973'te yaşadığı petrol krizi, ikincisi ise 1970lerin sonunda hızla gelişen ekonomi ile birlikte yabancı iş gücü göçüdür.

1973 'te Japonya'da bir petrol krizi yaşanmıştır. Bunun sonucunda dikkatler petrol çıkartan ülkelere yöneltilmiş, çoğunluğu Müslüman olan bu ülkeleri tanımaya çalışmaya başlamışlardır. İslam üzerine yapılan araştırmalar ülkede tekrar hız kazanmış, haberlerde Müslüman ülkelerden bahsedilmeye başlanmış ve Arapça kurslarına talep artmıştır. Bir önceki dönemde İslami ülkelere eğitim amaçlı giden Japon Müslümanların İslam, kültür ve dil bilgilerine ihtiyaç duyulmuş, birçoğu üniversitelerde, ticari şirketlerde, petrol, finans ve inşaat ile ilgili şirketlerde iş bulmuşlardır. Aynı savaş öncesi dönemde olduğu gibi, ülkede İslam’a olan ilgide hızlı bir artış olmuştur..$^{38}$

1970'lerin sonlarına gelindiğinde ise, İkinci Dünya Savaşı'nın izlerini silmek için tüm gücü ile çalışan Japonya, hızla endüstrileşmeye başlamış ve ekonomik alanda iyileşerek bubble economy/balon ekonomi diye adlandırılan döneme girmiştir. Ülkenin gelişmesi, şehirleşmenin artışı ve kişi başına düşen gelirin yükselmesi ile 3K diye anılan kitanai (kirli), kiken (tehlikeli) ve kitsui (zor) düşük gelirli işlerde çalışmak isteyecek kişilerin sayısı ciddi bir biçimde azalmış ve sıkıntı oluşturmaya başlamıştır. ${ }^{39}$ Bu dönemi takiben 1980'lerde, karşılıklı kısa dönem vize muafiyeti olan Endonezya, Pakistan, Bangladeş ve İran gibi çoğunluğu Müslüman ülkelerden Japonya'ya iş göçü başlamıştır. Çoğunluğu yirmi ve otuzlu yaşlardaki bekar erkeklerden oluşan bu göçmenler kısa dönem vizeler ile Japonya'ya gelmiş, ikinci el otomotiv, inşaat ve gıda gibi sektörlerde iş bulmuştur. Bir kısmı ise kısa dönem vizelerinin bitişi sonrası ülkelerine dönmemiş ve kaçak olarak kalıp Japon kadınlar ile evlenerek evlilik vizesi sayesinde ülkedeki yaşamlarına devam etmişlerdir. ${ }^{40}$

1984 yılında tahmin edilen Müslüman göçmen nüfus 5,341'tir; bunların 4,481'i Asya ülkelerindendir. Bunların 1,433'ünün Endonezyalı, 627'sinin Pa-

38 Higuchi Mimasaka, 『日本人ムスリムとして生きる』(Japon Müslüman Olarak Yaşamak) (Tokyo: Kosei Shuppan, 2007), 159-160.

39 Mike Douglass; Glenda S. Robert, "Japan in a Global Age of Migration", Japan and Global Migration - Foreign Workers and the Advent of a Multicultural Society, ed: Mike Douglass ve Glenda S.Roberts (London: Routledge, 2000), 6.

40 Keiko Sakurai, “Muslims in Contemporary Japan”, Asia Policy, No: 5 (2008): 72-76. 
kistanlı, 538'inin İranlı, 402'sinin ise Bangladeşli olduğu tahmin edilmektedir. Bunlar dışında Türkiye, Arabistan, Afganistan gibi ülkelerden de 100'er civarında göçmen bulunmaktadır. 2000'li yıllara gelindiğinde ise tahmini Müslüman göçmen sayısı 47,547'yi bulmuştur ve bunların 43,736'sı Asya ülkelerindendir. 16,870 kişi Endonezya, 7,123 Pakistan, 6,105 İran ve 6,336 Bangladeş göçmenidir. Türkiyeli göçmenlerin sayısı da 1421'i bulmuştur. 1984 yılında toplam yabancıların arasında Müslüman göçmenlerin oranı yalnızca \%0.4 iken 2004 yılında \%3'e ulaşmıştır. ${ }^{41}$

\section{Güncel Durum}

Göçmen Müslümanların Japonya'daki Müslüman nüfusun \%80-90 kadarını oluşturdukları tahmin edilmektedir. ${ }^{42} 2018$ 'de yayınlanan bir makaleye göre Japonya'da son yıllarda 140,000-150,000 civarı Müslüman yaşamaktadır. Güney Asya ve Güneydoğu Asyalı Müslüman göçmenler çoğunluğu oluşturmaktadır. Ayrıca göçmenlerin \%70'i de erkektir. ${ }^{43} 2004$ yılı yabancı nüfus istatistiklerine göre ise 2004'te Japonya'da bulunan göçmen Müslümanların \%15'i geçici ziyaretçi vizesine, \%33'ü çalışma yahut diplomatik vizeye, \%16's1 öğrenci yahut stajyer vizesine, \%26'sı ise bir Japon vatandaşının eşi ya da çocuğu olarak kalıcı vizeye sahiptir. Bunun yanında \%10'luk bir oranda da vizesi bittiği halde ülkede kalmaya devam eden kaçak göçmen bulunmaktadır. ${ }^{44}$ 2019 yılında yayınlanan başka bir araştırmaya göre ise 2018'de Japonya'daki Müslüman nüfus toplam 152,744'tür. Bunların 8,244'ü bir Japon vatandaşı ile evlidir, 36,759'u ise Japon vatandaşıdır. ${ }^{45}$

Japonya'daki güncel göçmen Müslüman nüfus çalışma koşullarına göre dört kategoride incelenebilir. İlk kategoridekiler ülkeye kısa süreli gelip vize süresini aşarak vasıfsız işlerde çalışmaya devam eden göçmenlerdir. Bu grup içerisinde Türkiyeli göçmenler de bulunmaktadır. Bu gruptaki göçmenler 3 aylık vize muafiyetinden faydalanarak Japonya'daki bir yakınının yanına gidip onun yanında ya da vasıtasıyla iş bularak çalışmaya devam etmektedir. Ekonomik sebepler ile Türkiye'den Japonya'ya göçte özellikle Fatsalı göçmenlerin yoğunluğu dikkat çekicidir. 1988'de Japonya'ya yolu düşüp orada

\footnotetext{
${ }^{41}$ Hiroshi Kojima, "Variations in Demographic Characteristics of Foreign "Muslim" Population in Japan: A Preliminary Estimation", The Japanese Journal of Population, Vol.4:1 (2006): 119.

42 Sakurai, "Muslims in Contemporary Japan", 70.

43 Okai，「ムスリム・コミュニティと地域社会 - イスラーム団体の活動から「多分化共生」を 再考する」(Müslüman ve Yerel Topluluklar: İslami Organizasyonlar Bağlamında “Çokkültürlü Ortakyaşam"1 Tekrar Düşünmek), 183.

44 Sakurai, "Muslims in Contemporary Japan", 73.

45 Tanada, 『世界と日本のムスリム人ロ-2018 年』(Dünyada ve Japonya'da Müslüman Nüfus, 2018), 259.
} 
kalmayı tercih eden bir Fatsalı göç yolunu açmış, onun ardından 1990'ların başlarında Fatsa'dan Nagoya'ya bir göç dalgası gerçekleşmiştir. Çoğunluğunu memleketlerinde ekonomik sıkıntılar çeken ve daha iyi iş imkanları arayan erkeklerin oluşturduğu bu grup, bir yakınları vasıtasıyla Japonya'dan iş teklifi alıp vize muafiyetinden faydalanarak Japonya'ya gidip buldukları işlerde kazandıklarını geride bıraktıkları ailelerine göndermektedirler. Tahminlere göre Japonya'da 4000 kadar Fatsalı göçmen bulunmaktadır ancak büyük bir kısmı yasal kalış ve iş iznine sahip olmadığından tam ve resmi olarak ne kadar olduklarını bilmek mümkün değildir. ${ }^{46}$

İkinci kategorideki göçmenler stajyer vizesine sahip göçmenlerdir. Stajyer göçmenler Japonya'nın iş gücü açığına bulduğu geçici çözümlerden birisidir. Stajyerlerin Japon şirketlerinde kısa dönem çalışıp hem Japonca eğitimi ve teknik eğitim almaları hem de çalıştıkları dönemde firmanın iş gücü ihtiyacına bir dereceye kadar çözüm olmaları hedeflenmektedir. Japonca eğitimi ve teknik eğitim alan bu kimseler ya eğitimleri bittiğinde ülkelerine dönmekte ya da Japonya'da kalıp çalışmaya devam etmektedirler. 1991 yılı istatistiklerine göre Japonya'da 43,649 stajyer göçmen bulunmaktadır ve bunların 4,307'si Malezya, 3,883'ü Endonezya gibi Müslüman nüfusun yoğun olduğu ülkelerdendir. ${ }^{47}$ Japonya'daki Endonezyalı ve Malezyalı stajyerlerin hepsi Müslüman olmamakla birlikte, stajyer programı vesilesiyle son 30 yılda bu ülkelerden Japonya'ya Müslüman göçü de artışa geçmiştir. ${ }^{48}$

Üçüncü grup Müslüman göçmenler kendi işlerini kurmuş ve bir süredir Japonya'da yaşamakta olan göçmenlerdir. Bu grup, 1980'lerde gelip önce vasıfsız işlerde çalışmaya başlayan ve sonradan kendi işlerinin sahibi olan Bangladeşli, Pakistanlı, İranlı ve Türkiyeli göçmenlerdir. Genellikle ikinci el araba ihracatı, helal gıda ithalatı ve restoran işletmeciliği gibi işleri vardır. Kısa dönemli olan ilk iki grubun aksine bu grup ülkeye yerleşmiş, hatta Japon kadınlar ile de evlenerek ülkede aile kurmuştur.

Dördüncü bir grup da Japon üniversitelerinde okuyup çalışan öğrenci ve akademisyenlerdir. 2015'te yayınlanan bir araştırmaya göre çoğunluğu Müslüman olan ülkelerden gelen 7000 öğrenci vardır. Bunların 4,703'ü Güneydoğu Asya ülkeleri Endonezya ve Malezya'dan, 1,551'i Güney Asya ülkeleri

46 Esra Demirkol, “Çin İşi Japon İşi, Acep Bu Kimin İşi?” Fatsa'dan Nagoya'ya Bir Göç Hikayesinin Gölgesindeki Kadınlar", Kebikeç, No: 32 (2011): 76.

47 Hiroshi Komai, Migrant Workers in Japan (London: Kegan Paul International, 1995), 42.

48 Komura,『日本とイスラームが出会うときーその歴史と可能性』, 69-72. 
Bangladeş ve İran'dan, 336'sı Suudi Arabistan'dan, 226'u Misır'dan ve 191'i de Özbekistan'dandır. ${ }^{49}$

Müslüman nüfusun artması ile ülkedeki cami sayısı da artmaya başlamıştır. Hint ve Tatar Müslümanların gayretleri ile açllan Kobe, Nagoya ve Tokyo camilerinden sonra 1990’ł yıllara kadar cami sayısında fazla bir artış olmamıştır. Tatar ve Hintli Müslümanların çoğunun savaş dönemi ve sonrasında Japonya'dan ayrılması ve 1945'ten 1980'lere kadar Japonya'da çok da fazla Müslüman olmaması bunun sebeplerinden biridir. 1980'lerde Japonya'ya gelip yerleşen çoğunluğu Endonezya, Bangladeş, Pakistan ve İran'dan olan göçmen gruplar cami inşa edebilecek ekonomik ve sosyal konfora ulaşıncaya kadar Cuma namazları, teravih ve bayram namazları için göçmen topluluğa ait üyelerin evlerinde ya da mescit niyetine kiralanan dairelerde toplanmıştır. Müslüman göçmen nüfus ekonomik ve sosyal açıdan rahatlayıp kendilerinden ve Japonya'daki yaşamlarından emin olmaya başladıktan sonra, yaşadıkları farklı bölgelerde cami inşaatı çalışmalarına başlanmıştır. Cami inşası için kendi birikimlerini bağışladıkları gibi anavatanlarından da bağış toplamışlardır. ${ }^{50}$ Japonya genelinde cami sayısı $2007^{\prime}$ de $38^{\prime}$ e ulaşmışs ${ }^{51}$, $2014^{\prime}$ te 80 olmuş ${ }^{52}$ ve en son 2017'de 96'yı bulmuştur ve onlarca yeni cami de şu anda planlama sürecindedir. ${ }^{53}$

Japonya'daki Müslümanların -Japon yahut göçmen- Müslüman nüfusun azınlıkta olduğu her ülkede olduğu gibi, helal yemek, namaz kılacak yer ve mezarlık yeri bulmak gibi belli başlı problemleri bulunmaktadır. Özellikle yoğun göçün başladığı 1980'li yıllarda Müslüman göçmenler, işverenlerin İslam hakkında çok fazla bilgi sahibi olmaması sebebiyle iş saati içerisinde namaz kılma konusunda problem yaşamıştır. Ancak süreç içinde işverenlerin İslam'1 ve çalışanlarının ihtiyaçlarını anlamaya başlamasıyla birlikte, problem mesai içinde namaz için ayrılan vakti gün sonunda telafi etme gibi anlaşmalarla çö-

49 Sachiko Nakano; Yuri Okunishi; Tomoko Tanaka,在日ムスリム留学生の社会生活上の困難」 (Japonya'daki Müslüman Öğrencilerin Sosyal Hayatta Karşılaştıkları Zorluklar), 『岡山大学 大学院社会文化科学研究科紀要』(Okayama University Graduate School of Social and Cultural Science Bulletin), No: 39 (2015): 137.

50 Kawakami Yasunori, "Local Mosques and the Lives of Muslims in Japan", The Asia-Pasific Journal, Vol: 5:5 (2007): 1-7.

51 Sakurai, “Muslims in Contemporary Japan", 79.

52 Komura,『日本とイスラームが出会うときーその歴史と可能性』 (Japonya ve İslam'ın Karşılaşma Ani), 89.

53 Okai, 「ムスリム・コミュニティと地域社会 - イスラーム団体の活動から「多分化共生」を 再考する」(Müslüman ve Yerel Topluluklar: İslami Organizasyonlar Bağlamında “Çokkültürlü Ortakyaşam"1 Tekrar Düşünmek), 184. 
zülmeye çalışılmıştır. ${ }^{54}$ Yabancı turist hedefinin son yıllarda Çinli turistlerden Güneydoğu Asyalı turistlere kayması da, Müslüman turistlere yönelik çalışmaların artmasına sebep olmuştur..$^{55}$ Ülkede, özellikle büyük şehirlerde, helal yemek seçenekleri hızla artmakta, yeni helal sertifikalı restoranlar açılmakta, bilinen Japon restoran zincirleri özel helal menüler oluşturmaktadır. Marketlerde helal hazır gidaya rastlamak son derece normal kabul edilebilecek bir durum haline gelmiştir. Müslümanlar tarafından inşaları devam eden cami ve mescitlerin yanı sıra büyük alışveriş merkezlerinde, büyük lunaparklarda, otobüs terminallerinde ve tren istasyonlarında ve belli başlı turistik yerlerde Japon işletmeciler tarafından açılmış mescit/dua odalarına sıklıkla rastlanır hale gelmiştir.

Hedeflenen turist demografisine göre yapılan bu değişiklikler, Japonya'da yaşayan göçmen ve yerli Müslümanların dini yaşamlarını da pratik açıdan kolaylaştırmaya başlamıştır. Ancak bu, onların ülke tarafından tam olarak yerleşik olarak kabul edildikleri anlamına da gelmemektedir. Japonya'daki göçmen nüfus -Müslüman ya da değil- yaşamlarının çoğunu burada geçirmiş dahi olsalar ülkeye kabul edilme ya da yaşadıkları toplum tarafından kabul edilme gibi konularda sıkıntılar yaşamaktadır. 2010 tarihli bir haberde, o dönem 800.000 nüfusa sahip Hamamatsu şehrinde çoğunluğu Brezilyalı, Perulu ve Endonezyalı 30.000 yabancı yaşadığı, şehir içinde market, restoran ve okulları olduğu halde, yerel Japon halkının aralarında yaşayan bu büyük yabancı nüfusundan bihaber olduğu belirtilmektedir. ${ }^{56}$ Yabancı varlı̆̆ 1 ve iş gücü geçici bir durum olarak değerlendirilmektedir. "Fabrikaların makineleşmesi ve Japonya'nın yoğun iş gücü gerektiren endüstrilerinin yurt dışına taşınması ile" ${ }^{57}$ artık yabancı iş gücüne ihtiyaç kalmayacağı düşünülmektedir. 1990'larda Japonya'ya çalışmak için dönmeye başlamış Brezilyalı Japonlar bile aslen Japon olmalarına rağmen başka bir ülkede doğup o kültürde yetişmiş olmaları sebebiyle, Japon toplumunda yerel olarak kabul görmekte zorlandıklarını, kendilerini evde hissetmediklerini ifade etmektedirler. ${ }^{58}$

54 Keiko Sakurai,『日本のムスリム社会』(Japonya'da Müslüman Topluluklar). (Tokyo: Chikuma Shinso, 2003), 101.

55 Komura,『 日本とイスラームが出会うときーその歴史と可能性』 (Japonya ve İslam'ın Karşlaşma Anı), 86-87.

56 Natsuko Fukue, "Nonprofit brings together foreign, Japanese residents in Hamamatsu", The Japan Times, https://www.japantimes.co.jp/news/2010/03/13/national/nonprofit-brings-together-foreign-japanese-residents-in-hamamatsu/, erişim tarihi: 11 Eylül 2020.

57 Douglass; Robert, "Japan in a Global Age of Migration", 2.

58 Kyodo News, "Yearning for Multiculturalism -Young Foreign Residents Seek Identity That can be Recognized by Both Japanese and Themselves", The Japan Times, https://www.japan- 
Her ne kadar ilk nesil göçmen Müslümanlar ekonomik açıdan rahatlamış ve düşük gelirli işlerden ayrılıp kendi işlerini kurmaya başlamış olsalar $\mathrm{da}^{59}$, göçmen nüfusun ortak olarak ev bulma, düzenli bir iş bulma ve sosyal hizmetler konularında sıkıntıları devam etmektedir. ${ }^{60}$ Toplum içinde yerleşik unsur olarak kabul edilmelerinin kolay olmayışı ve kendilerine bir yer edinemeyişleri ise başarılı bir şekilde sosyalleşme ve topluma adapte olmalarının önüne geçebilmektedir. Fakat farklı ülkelerden Japonya'ya gelen insanların ülkede yerleşik olarak kolay kolay kabul görememeleri, ne Japonya'nın İslam hakkında olumsuz bir yargısı olması sebebiyle olmaktadır ne de yalnızca Müslümanların yaşadığı bir problemdir. Bunun sebebi Japonya'nın başka bir ırktan olan kimseyi, Japon yaşantısına uyum sağlayamayacakları düşüncesi ile ${ }^{61}$ yerleşik olarak görememe ve kabul edememesi ile alakalı bir tutumdur. Yabancı birinin ne Japon toplumunun adet ve kurallarına uyum sağlayabileceği ne de Japoncayı bir Japon kadar iyi öğrenip kullanabileceği ${ }^{62}$, Japonya'da doğmuş ve yetişmiş olsa dahi bir Japon'un tutum ve davranışlarına sahip olamayaca$\breve{g}^{163}$ gibi düşünceler bir yabancının Japonya'ya yerleşmekte ve toplumun bir bireyi olarak yaşamakta zorlanacağı algısına sebebiyet vermektedir. Göçmenler turist ya da misafir olarak algılandıkları sürece kabul görmekte, memnun edilmeye ve ihtiyaçları elden geldiğince giderilmeye çalışılmaktadır. Ancak Japonya'ya yerleşmek istediklerinde kendilerini toplumun bir parçası olarak kabul edilmedikleri ve hatta görmezden gelindikleri ${ }^{64}$ bir durum içerisinde bulmaktadırlar. Bununla birlikte Müslüman göçmenler, toplum hayatında kabul görmekte yaşadıkları sıkıntıların kendileri yüzünden yahut Japonların

times.co.jp/news/2010/12/10/national/yearning-for-multiculturalism/, erişim tarihi: 11 Eylül 2020.

Sakurai,『日本のムスリム社会』(Japonya'da Müslüman Topluluklar), 57-59.

60 Douglass; Robert, “Japan in a Global Age of Migration”, 2.

61 Erin Aeron Chung, Immigration \& Citizenship in Japan, (Cambridge:Cambridge University Press, 2010), 3.

62 Katherine Tegtmeyer Pak, "Foreigners are local citizens too - Local Governments Respond to International Migration in Japan", Japan and Global Migration - Foreign Workers and the Advent of a Multicultural Society, ed. Mike Douglass, Glenda S. Roberts (London: Routledge, 2005), 253.

63 Kosaku Yoshino, "The Discourse on Blood and Racial Identity in Contemporary Japan", The Construction of Racial Identities in China and Japan, ed. Frank Dikötter (Hong Kong: Hong Kong University Press, 1997), 203.

64 Takashi Machimura, "Local Settlement Patterns of Foreign Workers in Greater Tokyo Growing Diversity and Its Consequences", Japan and Global Migration - Foreign Workers and the Advent of a Multicultural Society, ed. Mike Douglass, Glenda S. Roberts (London: Routledge, 2005), 193. 
İslam düşmanlığı gibi sebeplerle olmadığının farkındadırlar ve ev sahiplerine bu konuda kırgın değillerdir. ${ }^{65}$

Helal yemek seçeneklerinin ve mescit ve camilerin artışı, mezar yerlerinin ayarlanması ile İslami pratiklere dair problemler hızla azalmaktayken, toplumun kalıcı bir ferdiymiş gibi kabul görmekte yaşadıkları sıkıntılar henüz aynı hızla çözülmemekte ve bu durum göçmenlerde kimlik problemlerine sebebiyet verebilmektedir. Asyalı Müslüman göçmenlerin kimlik kaygıları üzerine yapılan bir çalışmada, göçmenlerin sürekli Asyalı göçmen kimliklerinin ve/ veya Müslüman kimliklerinin Japon toplumunca yanlış anlaşıldığ da endişe yaşadıkları tespit edilmiştir. Ana vatanlarından getirdikleri ve yetişkin yaşlarına kadar toplum içinde ön planda olan kimlikleri ile Japon toplumu içinde başarılı bir sosyalleşme gerçekleştirememeleri ve yeni ülkelerinde başarılı bir bireysel ve sosyal kimlik oluşturamamaları onların kimlik bunalımları yaşamalarına sebebiyet vermektedir. Araştırmaya göre, göçmenlerin kimlik bunalımının üstesinden gelmek için farkında olarak ya da olmayarak yöneldikleri üç ayrı yol bulunmaktadır. İlk grup göçmen Müslümanlar değiştiklerini, eski kendilerinin kalmadığını ve neredeyse Japonlaştıklarını ifade ederek, Japon toplumu içerisinde artık kabul görmeleri gerektiği beklentisi taşımaktadırlar. Bilinçli yahut değil, ev sahibi toplumun içinde asimile olarak ve onlar tarafından sosyal olarak kabul görerek kim olduklarına dair yaşadıkları çelişkilerin üstesinden gelmeyi arzulamaktadırlar. İkinci grup, kim olduklarının Japonlar tarafından yanlış anlaşıldığı düşüncesindedir ve bunun sebebi olarak da Japonya'daki İslam ve Müslümanlar hakkındaki kısıtlı bilgiyi görmektedir. Kendilerini hala ana vatanlarının kültürü ve dini ile özdeşleştirerek, Japon toplumunun kendileri hakkındaki yanılgılarını düzeltip toplum içinde kabul görmeyi hedeflemektedirler. Üçüncü ve son grup ise din konusunda kendilerini daha çok geliştirip daha iyi Müslüman olmaları gerektiğine inananların grubudur. Böylelikle, yine farkında yahut değil, dini ve kültürel kimliklerine daha sıkı bağlanarak ve öz benliklerini güçlendirerek, Japonlar tarafından kabul görüp görmediklerine aldırmaksızın sağlam bir kimlik algısı ile yaşamlarına devam edebileceklerdir. Müslüman göçmenlerin kimlik kaygıları üzerine yapılan bu araştırmada 24 kişi ile röportaj yapılmış, bunların 11 'inin ilk grupta, 9'unun ikinci grupta, yalnızca 4 'ünün ise son grupta olduğu tespit edilmiştir. ${ }^{66}$

65 Michael Penn, "Public Faces and Private Spaces: Islam in The Japanese Context", Asia Policy, No: 5, Ocak 2008.

66 Akiko Onishi, "Becoming a better Muslim - Identity Narratives of Muslim Foreign Workers in Japan", Transcultural Japan - At the Borderlands of Race, Gender, and Identity, ed. David Blake Willis and Stephen Murphy-Shigematsu (London: Routledge, 2008), 217-234. 
2005-2006 yıllarında çoğunluğu 20'li ve 30'lu yaşlarında 149 göçmen Müslüman ile yapılan bir anket çalışmasında ise katılımcıların \%76.5'i Japonya'daki yaşamlarından memnun ve çok memnun olduklarını belirtmişlerdir. \%19.5' $\mathrm{i}$ Japon hayatına tamamen uyum sağladıklarını ifade ederken, \%61.7'si neredeyse uyum sağladıklarını söylemiştir. Hiç uyum sağlayamadıklarını söyleyenlerin oranı ise yalnızca \%3.4'tür. Japonya'da 10 yıl ve üzeri yaşayan katılımcılardan hiç uyum sağlayamadığını söyleyen kimse olmamıştır. En çok sıkıntı çektikleri konuların başında \%38.3 ile kendilerini Japonca yeterince iyi ifade edememek, \%36.2 ile yiyecek, \%32.2 ile anavatanları hakkındaki endişeleri gelmektedir. Japon gelenekleri hakkında \%14.1, Japonların düşünce biçimleri hakkında \%18.8, işyeri ilişkileri hakkında \%10.1 ve işyeri dışındaki insan ilişkileri hakkında ise \%10.1 oranlarında sıkıntıları bulunmaktadır. Problemlerine ve Japonya'daki yaşam sürelerine detaylı olarak bakıldığında, dil konusunda zorlananların \%42.1'ini Japonya'da yalnızca 2 yıldır yaşayanların oluşturduğunu, ülkede 10 yıl ve üzeri bir süredir yaşayanların ise yalnızca \%8.8'inin böyle bir problemi olduğu görülmektedir. Aynı şekilde, insan ilişkileri konusunda sıkıntı yaşayanların \%36'sını 2 yıllık göçmenler oluşturmaktayken, ikamet süresi 10 yıl ve üzeri olanların sadece \%8'i insan ilişkilerinde zorlanmaktadır. Ayrıca, Japon geleneklerine uyum sağlamakta zorlanan \%14.1'in \%61.9'unu 2 yıllık göçmenler, \%23.8' ini 2-5 yıllık göçmenler, \%9.5'ini 5-10 yıllık göçmenler oluşturmaktayken 10 yıl ve üzeri Japonya'da yaşayan göçmenlerin hiçbiri bu konuda sıkıntı çekmemektedir. Bu oranlara bakıldığında, göçmenlerin çoğunun genel olarak Japonya'daki hayatlarından memnun olduğu, ülkede uzun süre kalıp dile ve adetlerine aşinalıkları arttıkça da aslında ülkeye uyum sağlamaya başladıkları ve insan ilişkilerinde yaşadıkları sıkıntıların azaldığı gözlemlenmektedir. ${ }^{67}$

Günümüz Japonya'sında her ne kadar kayda değer bir Müslüman göçmen topluluğu varlığını sürdürüyor olsa da, gerek 150 yıllık göç tarihinde göçün istikrarlı bir şekilde devam etmemesi, gerekse Japon toplumu ve siyasilerinin bir göçmeni kolay kolay yerleşik olarak kabul edememesi gibi sebeplerle göçmenler, hala geçici ve misafir olarak kabul edilmektedir. Bu nedenlerden dolayı topluma aidiyet kurmada ve kimlikleri konusunda sıkıntılar yaşamaktadırlar. Fakat ülkede geçirdikleri süre, Japon diline ve kültürüne aşinalıkları ve uyumları arttıkça, Japonya'daki yaşamlarından memnuniyetlerinin de arttığı gözlemlenmektedir.

Waseda Üniversitesi Beşeri Bilimler Fakültesi Asya Sosyal Teori Laboratuvarı,「在日ムスリ 么調査」 (Japonya'da Yaşayan Müslümanlar Anketi), 『関東大都市圈調査』(Kanto Metropol Alanı Araştırması), (Tokyo: Waseda Üniversitesi, 2006), 65-70. 


\section{Sonuç}

Japonya'ya Müslüman göçünün yaklaşık olarak 150 yıllık bir tarihi vardır. 1800'lerin sonlarında Hintli Müslümanlar ile başlayan göçler, 1900'lerin başlarında Türk-Tatar Müslümanlar ile devam etmiştir. İkinci Dünya Savaşı sonrası bu göçmen grupların ülkelerine dönmeleri ya da başka ülkelere göç etmeleri ile Japonya'da Müslüman göçmen sayısı iyice azalmıştır ve Müslüman göçü açısından durgun bir döneme girilmiştir. 1970'lerin hızlı ekonomik gelişmesini takiben Orta Doğu, Güney Asya ve Güneydoğu Asya ülkelerinden Japonya'ya yoğun iş göçü başlamış, 1990'lardan sonra ise staj ve eğitim sebepli göçler de hız kazanmıştır.

2018 istatistiklerine göre Japonya'da son dönemde 140,000-150,000 arası Müslüman olduğu tahmin edilmektedir. Göçmenlerin dinlerine dair resmî herhangi bir istatistik olmadığından, Müslümanların sayısı çoğunluğu Müslüman olan ülkelerden gelen göçmenler hesaplanarak tahmin edilebilmektedir. Müslüman nüfusun da \%80-\%90'ının göçmen Müslümanlar, kalanının Japon Müslümanlar olduğu düşünülmektedir. Göçmen Müslümanlar özellikle son dönemde İslam dininin pratiklerini uygulamada büyük sorunlarla karşılaşmamaktadırlar. Helal yiyecek imkânları artmıs, mescit sayılarının artması ile gündelik hayatın içerisinde namaz kılma kolaylaşmış, İslami organizasyonların satın aldığı Müslüman mezarlıklar ile defin konusunda sıkıntı yaşanmamaya başlanmıştır.

Ancak, İslami pratikler konusunda yaşamları gittikçe kolaylaşan göçmen Müslümanlar, yine de kendilerini Japon toplumunun kalıcı bir ferdi gibi hissetme konusunda sıkıntılar yaşamaktadırlar. Bunun iki sebebi olduğu gözlemlenmektedir. Birincisi, 150 yıl boyunca bir gelip bir giden göç dalgası sebebiyle ülkede istikrarlı bir Müslüman yerleşimi oluşamamıştır. Bu sebeple de, göç tarihi aslında uzun olmasına rağmen, Müslüman nüfus istikrarlı bir şekilde artmamış, göçmen ikinci nesil ancak son zamanlarda Japon toplumunda yerlerini almışlardır. Göçün istikrarlı devam etmemesinin ve Müslüman göçmenlerin bir dönem var olup bir dönem ortalıkta görünmemelerinin Japon halkı nezdinde göçmenlerin geçici olduğu algısının oluşmasına sebep olduğu düşünülebilir. İkinci olarak da, Japon toplumunda yabancının, Müslüman yahut değil, sürekli yabancı olarak kalacağı, Japon kültür ve adetlerine uyum sağlamakta, Japonca konuşmakta zorlanacağı düşüncesi de göçmen bir bireyin toplum tarafından yerleşik olarak kabulünü zorlaştırmaktadır. Bu durum göçmenlerin başarılı bir toplumsal kimlik oluşturmasının önünde engel olduğu için kimlik bunalımı yaşamalarına sebebiyet vermektedir. Ülkede yaşadıkları süre arttıkça ise, göçmen Müslümanlar sanılanın aksine dile ve kültüre uyum sağlayabilmekte, tatmin edici bireysel ve toplumsal ilişkiler kurabilmektedirler. 


\section{Kaynakça}

Aydın, Cemil. The Politics of Anti-Westernism in Asia - Visions of World Order in Pan-Islamic and Pan-Asian Thought. New York: Columbia University Press, 2007.

Cary, Otis. A History of Christianity in Japan - Protestant Missions. Michigan: Scholarly Press, 1970.

Chung, Erin Aeron. Immigration \& Citizenship in Japan. Cambridge: Cambridge University Press, 2010.

Demirkol, Esra. “Çin İşi Japon İși, Acep Bu Kimin İşi? Fatsa'dan Nagoya’ya Bir Göç Hikayesinin Gölgesindeki Kadınlar”. Kebikeç No: 32 (2011): 75-102.

Douglass, Mike. Robert, Glenda S.. "Japan in a Global Age of Migration". Japan and Global Migration Foreign Workers and the Advent of a Multicultural Society. ed. Mike Douglass ve Glenda S. Robert. London: Routledge, 2000: 2-35.

Dündar, Ali Merthan. Japonya'da Türk İzleri: Bir Kültür Mirası Olarak Mançurya ve Japonya Türk-Tatar Camiileri. Ankara: Vadi Yayınları, 2008.

Dündar, Ali Merthan. "An Essay on the Immigration of the Turk-Tatars to Japan". Annual Journal of the Asian Cultures Research Institute No: 48 (2013): 165-174.

Esenbel, Selçuk. "Japan's Global Claim to Asia and the World of Islam". American Historical Review Vol:109:4 (2004): 1140-1170.

Esenbel, Selçuk. "Abdürreşit İbrahim: “The World of Islam and the Spread of Islam in Japan" 1910”. PanAsianism - A Documented History, Volume I: 1850-1920. ed: Sven Saalar, Christopher W. A. Szpilman. Plymouth: Rowman \& Littlefield Publishers, Inc., 2011: 195-204.

Fukue, Natsuko. "Nonprofit brings together foreign, Japanese residents in Hamamatsu", The Japan Times. https://www.japantimes.co.jp/news/2010/03/13/national/nonprofit-brings-together-foreign-japanese-residents-in-hamamatsu/. Erişim tarihi: 11 Eylül 2020.

Green, Nile. "Shared Infrastructures, Informational Asymmetries: Persians and Indians in Japan, c.18901930". Journal of Global History No: 8 (2013): 414-435.

Hamanaka, Akira.「 時計から見た日本のイスラーム」(İstatistiklerle Japonya'nun İslam'ı), 『日本に 生きるイスラームー過去一現在一未来 』(Japonya'da Yaşayan İslam -Geçmiş-GünümüzGelecek). ed. Suudi Arabistan Büyükelçiliği Kültür Bölümü. Tokyo: Suudi Arabistan Büyükelçiliği Kültür Bölümü, 2010.

Japan Muslim Association. Brief History of the Associaton-Publication in Memory of the 50th Anniversary. Tokyo: Japan Muslim Association, 2005.

Kojima, Hiroshi. "Variations in Demographic Characteristics of Foreign "Muslim" Population in Japan: A Preliminary Estimation". The Japanese Journal of Population Vol.4:1 (2006): 115-130.

Komai, Hiroshi. Migrant Workers in Japan. London: Kegan Paul International, 1995.

Komatsu, Hisao. "Muslim Intellectuals and Japan: A Pan-Islamist Meditator, Abdurresit Ibrahim”. Intellectuals in the Modern Islamic World: Transmission, Transformation and Communication. ed. Stephane A. Dudoignon, Komatsu Hisao, Kosugi Yasushi. London: Routledge, 2006: 273-288.

Komatsu, Hisao. "Abdurresit İbrahim and Japanese Approaches to Central Asia". Japan on the Silk Road -Encounters and Perspectives of Politics and Culture in Eurasia. ed. Selçuk Esenbel. Leiden: Brill, 2018: 145-154. 
Komura, Akiko.『日本とイスラームが出会うときーその歴史と可能性』(Japonya ve İslam Karşılaştığında). Tokyo: Gendaishokan, 2015.

Komura, Akiko.『日本のイスラームー歴史・宗教・文化を読み解く』(Japonya'nın İslam'1 - Tarih, Din ve Kültürü Okumak). Tokyo: Asahi Shimbun Publications, 2019.

Kyodo News. "Yearning for Multiculturalism -Young Foreign Residents Seek Identity That can be Recognized by Both Japanese and Themselves". The Japan Times. https://www.japantimes.co.jp/news/2010/12/10/national/yearning-for-multiculturalism/ Erişim tarihi: 11 Eylül 2020.

Levent, Sinan. “Japan's Central Eurasian Policy: A Focus on Turkic Muslim Minorities”. Social Science Japan Journal Vol. 22: 1 (2019): 127-149.

Machimura, Takashi. "Local Settlement Patterns of Foreign Workers in Greater Tokyo - Growing Diversity and Its Consequences". Japan and Global Migration - Foreign Workers and the Advent of a Multicultural Society. ed. Mike Douglass, Glenda S. Roberts London: Routledge, 2005.

Markovits, Claude. The Global World of Indian Merchants , 1750-1947: Traders of Sind from Bukhara to Panama. Cambridge: Cambridge University Press, 2000.

Mimasaka, Higuchi.『日本人ムスリムとして生きる』(Japon Müslüman Olarak Yaşamak). Tokyo: Kosei Shuppan, 2007.

Mimasaka, Higuchi.「日本のイスラーム、戦後の歩みー20世紀後半から今まで」(Japonya'nın İslam'1, Savaş Sonrası Tarih - 20. Yüzyıldan Günümüze).『日本に生きるイスラーム 一過去一現在一未来 』(Japonya'da Yaşayan İslam -Geçmiş-Günümüz-Gelecek). ed. Suudi Arabistan Büyükelçiliği Kültür Bölümü. Tokyo: Suudi Arabistan Büyükelçiliği Kültür Bölümü, 2010.

Morimoto, Abu Bakr. Islam in Japan - Its Past, Present and Future. Tokyo: Islamic Center Japan, 1980.

Nakano， Sachiko; Okunishi，Yuri; Tanaka，Tomoko. 「在日ム对么留学生の社会生活上の困難」 (Japonya'daki Müslüman Öğrencilerin Sosyal Hayatta Karşılaş̧ıkları Zorluklar).『岡山大学大 学院社会文化科学研究科紀要』(Okayama University Graduate School of Social and Cultural Science Bulletin) No: 39 (2015): 137-151.

Numata, Sayako. "Fieldwork Note on Tatar Migrants from the Far East to the USA: For Reviews of Islam Policy in Prewar and Wartime Japan". AJAMES No: 28-2 (2012): 127-144.

Oishi, Takashi. "Indo-Japan Cooperative Ventures in Match Manufacturing in India: Muslim Merchant Networks in and beyond the Bengal Bay Region 1900-1930". International Journal of Asian Studies No: 1:1 (2004): 49-85.

Okai, Hirofumi.「ムスリム・コミュテテ代地域社会-イスラーム団体の活動から多分化共生再考する」(Müslüman ve Yerel Topluluklar: İslami Organizasyonlar Bağlamında “Çokkültürlü Ortakyaşam”1 Tekrar Düşünmek).『現代日本の宗教と多分化再生』(Günümüz Japonya’sında Din ve Çokkültürlülük). ed: Noriko Takahashi, Tatsuya Shirahase ve Sô Hoshino. Tokyo: Akashi, 2018: 181-203.

Onishi, Akiko. "Becoming a better Muslim - Identity Narratives of Muslim Foreign Workers in Japan". Transcultural Japan - At the Borderlands of Race, Gender, and Identity. ed: David Blake Willis ve Stephen Murphy-Shigematsu. London: Routledge, 2008: 217-236.

Penn, Michael, "Public Faces and Private Spaces: Islam in The Japanese Context", Asia Policy, No: 5, Ocak 2008. 
Sakurai, Keiko.『日本のム对么社会』(Japonya'da Müslüman Topluluklar). Tokyo: Chikuma Shinso, 2003.

Sakurai, Keiko. “Muslims in Contemporary Japan”. Asia Policy No: 5 (2008): 69-87.

Ulrich Brandenburg. "Imagining an Islamic Japan: Pan-Asianism's Encounter with Muslim Mission”. Japan Forum Vol: 0: 0 (2018): 1-24.

Worringer, Renée. "Hatano Uho: Asia in Danger, 1912". Pan-Asianism - A Documentary History Volume 1: 1850-1920. ed: Sven Saaler, Christopher W. A. Szpilman. Plymouth: Rowman \& Littlefield Publishers, Inc. 2011: 149-160.

Tanada, Hirofumi.『日本のモスク滞日ムスリムの社会的活動』(Japonya Camileri ve Japonya'da Yaşayan Müslümanların Sosyal Faaliyetleri). Tokyo: Yamakawa, 2015.

Tanada, Hirofumi.『世界と日本のム对ム人口-2018 年』(Dünyada ve Japonya'da Tahmini Müslüman Nüfus, 2018). 早稲田大学人間科学研究 (Waseda Üniversitesi Beşeri İlimler Fakültesi Araştırmalar1) Vol: 32-2 (2019): 253-262.

Tegtmeyer Pak, Katherine. "Foreigners are local citizens too - Local Governments Respond to International Migration in Japan". Japan and Global Migration - Foreign Workers and the Advent of a Multicultural Society. ed. Mike Douglass, Glenda S. Roberts London: Routledge, 2005.

Yasunori, Kawakami. "Local Mosques and the Lives of Muslims in Japan". The Asia-Pasific Journal Vol: 5:5 (2007): 1-7.

Yoshino, Kosaku. "The Discourse on Blood and Racial Identity in Contemporary Japan". The Construction of Racial Identities in China and Japan. ed. Frank Dikötter Hong Kong: Hong Kong University Press, 1997. 